Bryn Mawr College

Scholarship, Research, and Creative Work at Bryn Mawr

College

Spanish Faculty Research and Scholarship

Spanish

2014

\title{
Visual Fictions and the Archive of the Spanish Civil War
}

H. Rosi Song

Bryn Mawr College, hsong@brynmawr.edu

This article is published in the 2014 Hispanic Issue of MLN: Modern Language Notes

(http://muse.jhu.edu/journals/mln/v129/129.2.song.html).

Let us know how access to this document benefits you.

Follow this and additional works at: http://repository.brynmawr.edu/spanish_pubs

Part of the Spanish Literature Commons

\section{Custom Citation}

Song, H. Rosi, "Visual Fictions and the Archive of the Spanish Civil War," MLN: Modern Language Notes 129 (2014): 367-390.

This paper is posted at Scholarship, Research, and Creative Work at Bryn Mawr College. http://repository.brynmawr.edu/spanish_pubs/4

For more information, please contact repository@brynmawr.edu. 


\title{
Visual Fictions and the Archive of the Spanish Civil War
}

\author{
$\widetilde{\boldsymbol{e}}$ \\ H. Rosi Song
}

In memory of Don Rothman

In 2007, I received from a colleague a small black book by Martí Llorens with a dozen or so photographs of the Spanish Civil War entitled Memorias revolucionarias (1999). ${ }^{1}$ I was, at the time, preparing a presentation on the topic of memory and the Spanish Civil War and was intrigued by how family stories and photographs moved from private to public spaces through the advocacy of surviving relatives, even becoming, in the case of personal belongings, desirable objects in the marketplace. This little black book seemed to offer the perfect example of such transformation: a few snapshots that clearly belonged to different family albums, united in a small collectable object. In these images, men and women are seen in photographs taken during the war, which later were sent home with personal notes. Together, this collection and the messages they contained represented a moving and easily recognizable tribute to those who participated in and (were) lost in the war.

These snapshots made me reflect on what John Updike had written about this type of photographs, as he considered the appeal of these

\footnotetext{
${ }^{1}$ Special thanks to Camilla MacKay, Enric Bou, María F. Lander, and Homay King for their comments and support during the preparation of this essay and to Lázaro Lima for the little book.
} 
once private "homely staples." Having surfaced in the marketplace as collectables, the writer saw in this transition a persevering attraction, one that offered "windows, however smeary, into other lives," keeping the personal even when it became impersonal ("Visual Trophies"). Moving from the safe confines of immediate and personal recognition into a new space from which images can be freely observed and scrutinized without an attached narrative (or attached to different narratives), to me, the possibilities of this free circulation seemed infinite. I thought about how the appearance of such items would affect a historical archive, especially if we understood the archive as Foucault did, as a discursive practice that can be constructed as well as transformed. Or, as was the case with the archive of the Spanish Civil war, still debated among historians and questioned by activists and family members in search of relatives lost in the war, what role would (or should) these personal items play? The small book in my hands seemed to be engaging with those questions while inviting the viewer and the reader of the photographs' captions to be moved by the memories of the tragic event.

Photographer Martí Llorens published Memorias revolucionarias in 1999. ${ }^{2}$ Each image in the book is accompanied by a filing card with its title, along with a brief description of the origin of the snapshots and the writing contained in them. Memorias is around $4 \times 6$ inches, black, and reminiscent of a passport or a small travel notebook. ${ }^{3}$ The few photographs appear to condense the larger history of the war through images once destined for private family albums and presented as perfect vehicles to contemplate the past. Gazing at these images, I was captured by the way they played into my understanding of sepiacolored snapshots of days gone by: a mix of emotion, a sense of loss and nostalgia, curiosity for the private lives of those captured by the camera lens, a longing to know their stories and memories, the sorrow of a past tragedy. Looking even more closely, I marveled at the texture and authenticity of the photographs until I suddenly realized I was in the presence of a red herring. What made me assume their authenticity? How did I "know" these images were real? And soon, a more pressing question, how to read these snapshots once I discovered

\footnotetext{
${ }^{2}$ As a recipient of Endesa's grant, his biography and an introduction to his work was available at sintesis.endesa.es under the heading "Martí Llorens" (accessed 10 Dec. 2011). This entry is no longer available but the text can be found in the published collection commemorating the fifteenth anniversary of the Becas Endesa (2005).

${ }^{3}$ Information about the series which this book belongs to can be found at mestizo.org.
} 
them to be fictional, a collection of manipulated images prepared by a young Catalan photographer who happened one day to go by the shooting of the film Libertarias (Dir. Vicente Aranda, 1996)?

I begin my analysis of Martí Llorens's photographs with this personal anecdote to reflect on photographs of war in the context of the Spanish Civil War. These images provide an opportunity to reexamine our understanding of photographic images, their relationship to memory, and our connection to and understanding of the past.

\section{Photography and the Spanish Civil War}

Photography has had a special relationship with the Spanish Civil War. In fact, Susan Sontag described it as "the first war to be witnessed ('covered') in the modern sense: by a corps of professional photographers at the lines of military engagement and in the towns under bombardment, whose work was immediately seen in newspapers and magazines in Spain and abroad" (Regarding 21). Curiously, despite the suspicion that one of this war's most famous images, "The Death of the Loyalist Soldier" by Robert Capa, might have been staged, the photograph continues to be regarded as emblematic of that war and a symbol of the Republican cause. The controversy that has surrounded this photograph since the 1970s acquires poignancy when considered in relation to Llorens's work, and amid the controversy regarding the recollection of this war. I will return to this debate in the final section of my essay.

The photographs Capa and his fellow photographers Gerda Taro and David Seymour (Chim) took of the Spanish Civil War gave them international recognition. In the case of Capa, it brought him status as a celebrity that followed him through his career and his continued presence in war zones, both in Europe and later in Asia. In 2007, the works of the three photographers were exhibited at the International Center of Photography in New York City. ${ }^{4}$ This exhibit served to illustrate the myth surrounding the Spanish Civil War of the young and intellectuals joining in an international effort to aid the Spanish Republic against a Fascist uprising. Their photographs, published in photo journals and newspapers like Life, Ce Soir, Vu, Volks-Illustrierte, traveled the world, giving visual representation to a war that has, since then, become easily recognizable and lasting in the visual memory

\footnotetext{
${ }^{4}$ The exhibit "This is War! Robert Capa at Work" and "Gerda Taro" later traveled to the Museu Nacional d'Art de Catalunya in 2009.
} 
of many generations. Photographs of the Spanish Civil War attracted further popular attention with the rediscovery in 2007 of Capa's long-lost "Mexican suitcase." The sensational story of the recovery of Capa's negatives that accompanied the equally dramatic story of their original loss brought to light once again the high emotions that have characterized recollections of the Spanish Civil War. ${ }^{5}$ The works of other photographers such as that of Agustí Centelles and of Josep Brangulí have also received renewed attention. ${ }^{6}$

In situations of war, the popularity of photojournalism is explained by the power of realism attached to photographic images. This can also be explained by the double nature of photography, an apparent contradiction in which a particular moment is captured, only to immediately transcend it, producing a "visual history" of symbols and myths that infuse conflicts with meaning (Griffin 129-39). The idea is illustrated by Susan Sontag when she revisits Capa's photograph of the falling militiaman in Regarding the Pain of Others (2003). In a touching reflection on the relationship between photography, wars, and the suffering of others, Sontag writes about photography's mediation with memory. If her earlier work, On Photography (1977), focused on the ethics of seeing and acknowledged the "utilitarian" and evidentiary nature of photography, in her later essay she considers the power of their intervention: how photographs help us connect with the outside world. The arresting images of photojournalism are not the only ones capable of offering this connection. A pathos is also found in private photographs of the war, those snapshots taken for and by individuals to keep or send to family members. While still part of the general experience, these images, passed down between family members, create intimate networks of memory and affect, a private archive of war that links family members and communities through generations and structures of feeling. Staring back from family albums, the photographs sent and brought home by soldiers may lack the violence captured by photojournalism, but they likewise transcend the moment to stand as elegies of those who have lived and died in the war. ${ }^{7}$

\footnotetext{
5"The Capa Cache" narrates the story of this recovery. The negatives were later displayed at the ICP from September 2010 to August 2011.

${ }^{6}$ Centelles had an exhibit in NYC in 2011. The Centre de Cultural Contemporània de Barcelona organized a retrospective of Brangulî's photographs from 1909 to 1945 the same year. Information can be found at cccb.org.

${ }^{7}$ The family album has been the object of critical studies within Spanish culture. Yeon-Soo Kim provides a reading of its political and cultural applicability (17-21).
} 


\section{Memory, the Spanish Civil War and Family Photographs}

The political, social and cultural complexity of the issue of memory in Spain in relation to the Spanish Civil War became evident during the debate that took place surrounding what has come to be known in the press and the public as "Ley de Memoria Histórica." Proposed by the socialist party Partido Socialista Obrero Español (PSOE) in 2004, it is a law designed to extend the rights of victims of the Spanish Civil War and the dictatorship on both sides of the ideological divide, and to remove Francoist symbols from public places. The law was finally approved by Congress on October 31, 2007 and implemented on December 26 of the same year. The discussion about memory and the Spanish Civil War had been percolating from Spanish academic circles into the public as historians and activists were debating the repression that followed the end of the war and looking into recovery of the body of relatives killed during the dictatorship. ${ }^{9}$ As explained by Jo Labanyi, the key issue in this debate was how to address the memory of the violence of the Civil War and the dictatorship which, once kept as a private matter due to Francoist repression, was no longer hidden ("The Politics" 119-20)..$^{10}$

Paloma Aguilar has explained the particular view about the war that has prevailed in Spain. Franco's regime had deployed its memory to further its own ideological agenda, creating and exploiting the trauma around it, "building" consensus from fear of repeating this tragic event (25-26). ${ }^{11}$ Avoiding war and maintaining the "peace" achieved by the dictatorship meant that the memories of the Spanish Civil War were deemed dangerous. This view of the past influenced the way the legacy of the war was negotiated after Franco's death (26). Discussions about

\footnotetext{
"Ironically, the term "memory" was excluded from the title of the law because the Comisión Interministerial, responsible for drafting its text, decided that it was not the job of the government to interfere with the citizen's memory (Labanyi, "The Politics" 125). The Boletín Oficial de Estado calls it "Ley 52/2007, de 26 de diciembre, por la que se reconocen y amplían derechos y se establecen medidas en favor de quienes padecieron persecución o violencia durante la guerra civil y la dictadura." Available online at boe.es.

${ }^{9}$ Publications like Guerra civil. Mito y memoria (2006) or La guerra que nos han contado. 1936 y nosotros (2006) are some examples of this renewed interest in the memory of the war. Public concern and participation has increased since the foundation in 2000 of the Asociación para la Recuperación de la Memoria Histórica (ARMH) by Emilio Silva and Santiago Macías Pérez.

${ }^{10}$ This violence and repression have been well documented by historians such as Francisco Espinosa (2003), Casanova et al. (2004) and Paul Preston (2012).

${ }^{11}$ Pablo Sánchez rejects this fearmongering and the phrase "nunca más" [never again] as an epistemic paradigm to study the Spanish Civil War (132).
} 
the Spanish Civil War have remained thorny since, and the amnesty law of 1977 only helped to complicate this relationship as it shielded any crimes committed during the Franco era from persecution.

Given these circumstances, the unofficial title "Ley de Memoria Histórica" that stuck in the media is curious because the law does not adequately address what the popular title seems to suggest: collective memory. Even supporters of the law like ARHM's Emilio Silva criticized the law's insistence that memory is a private matter, avoiding questions such as the teaching of history in the education system. ${ }^{12}$ There is a failure to acknowledge that "historical memory" is collective and not personal; it is not the same as citizens having the right to express their personal memories in public (Labanyi, "Entrevista" 153-54; "The Politics" 120).

Perhaps it is precisely the lack of an official framework for the private memories and its traces that explains the currency of personal objects, especially family photographs, which are poised to create an alternate archive of the Spanish Civil War as they become public. ${ }^{13}$ Family photographs taken during the war, for instance, were collected in Catalonia to be showcased alongside the works of Capa, Taro and Chim when their exhibit traveled from the ICP to Barcelona in 2009. These family photographs are interesting to consider given their connection to collective (visual) memory and the past. Marianne Hirsch brings to our attention the conventionality of the family photo as a space of identification in which any viewer can participate in the conventions of familiar representation and therefore is allowed to be connected to an unfamiliar event. For Hirsch, this is a way to expand the postmemorial circle (251). While Beatriz Sarlo questions the need for such a concept given that unlived experiences are always mediated for others, she acknowledges the significance of the implication of subjectivity in this vicarious transmission of the past (128-32). Thus, the most important aspect of this remembrance is the possibility of connection via the intimate structure of the family through which we acquire, among other objects, images of the past. These pictures are able to bridge space and time "to foster an affiliative look that binds the photographs to one another and us to them" (Hirsch 253-54).

\footnotetext{
${ }^{12}$ Inversely, what the conservative Partido Popular criticized was "the clauses concerning the removal (or not) of Francoist symbols, such as street names, plaques, statues and monuments" (Labanyi, "The Politics" 125).

${ }^{13}$ We should highlight the initiative by Memorial Democràtic in Catalunya in the effort to create spaces for public remembrance (Guixé 580-85).
} 
I would argue that this dynamic applies not only to our own family photos but to family albums in general where we engage in the exercise of affiliative looking. The domestic space represented by the album allows a different way of looking, as the referents contained in the images are turned from individuals to generic family members where "the process of affiliative familial looking fosters and shapes the individual viewer's relationship to this collective memory: they can adopt these memories as their own postmemories" (Hirsch 254-55). Turning to the question of the connection of the photographic image to the past, its exposure to manipulation, and its archival nature, the Spanish Civil War is a fertile ground to explore the contestation of the past. It is within the concept of its archive-and maybe its (im) possibility-that I would like to situate my reading of Martí Llorens's photographs.

\section{Memorias revolucionarias}

Martí Llorens's photographs, situated in the intersection between image and narrative, signal their capacity to create memory. To aid in this exercise of recollection, the photographs in Llorens's book are introduced by a text written by Guillem Martínez who recounts the story of his uncle and his father and their experience during the early days of the war (see Fig. 1 and 2) ${ }^{14}$ Under the title "La vida no vivida," Martínez recounts a story which is not his own, but over which he expresses ownership since it is a story about a family member. He also embraces the memories produced by this "unlived" story because “[c] onservan la emoción, la densidad y la magia de los recuerdos no vividos" (n. p.). Martínez invites the viewers of Llorens's photographs to experience the seemingly private memories and stories contained in them.

The authors of these snapshots are sometimes identified and at other times only referred as to unknown or even as "un inglés," possibly a photojournalist or a member of the International Brigade. By the subjects portrayed in these shots and the war props surrounding them, like the truck painted with the acronym FAI (Federación Anarquista Ibérica) or the name "Columna Durruti," the viewer is able to identify the ideological bent of these fighters, men and women of the

\footnotetext{
${ }^{14} \mathrm{Each}$ one of the photographs in the original Memorias revolucionarias is spread in two pages: the image occupies the center of one page, and facing it, a "photograph" of the caption for the images. These images belong to the exhibition described later in the essay. Special thanks to Martí Llorens for his permission to reprint them in this essay.
} 


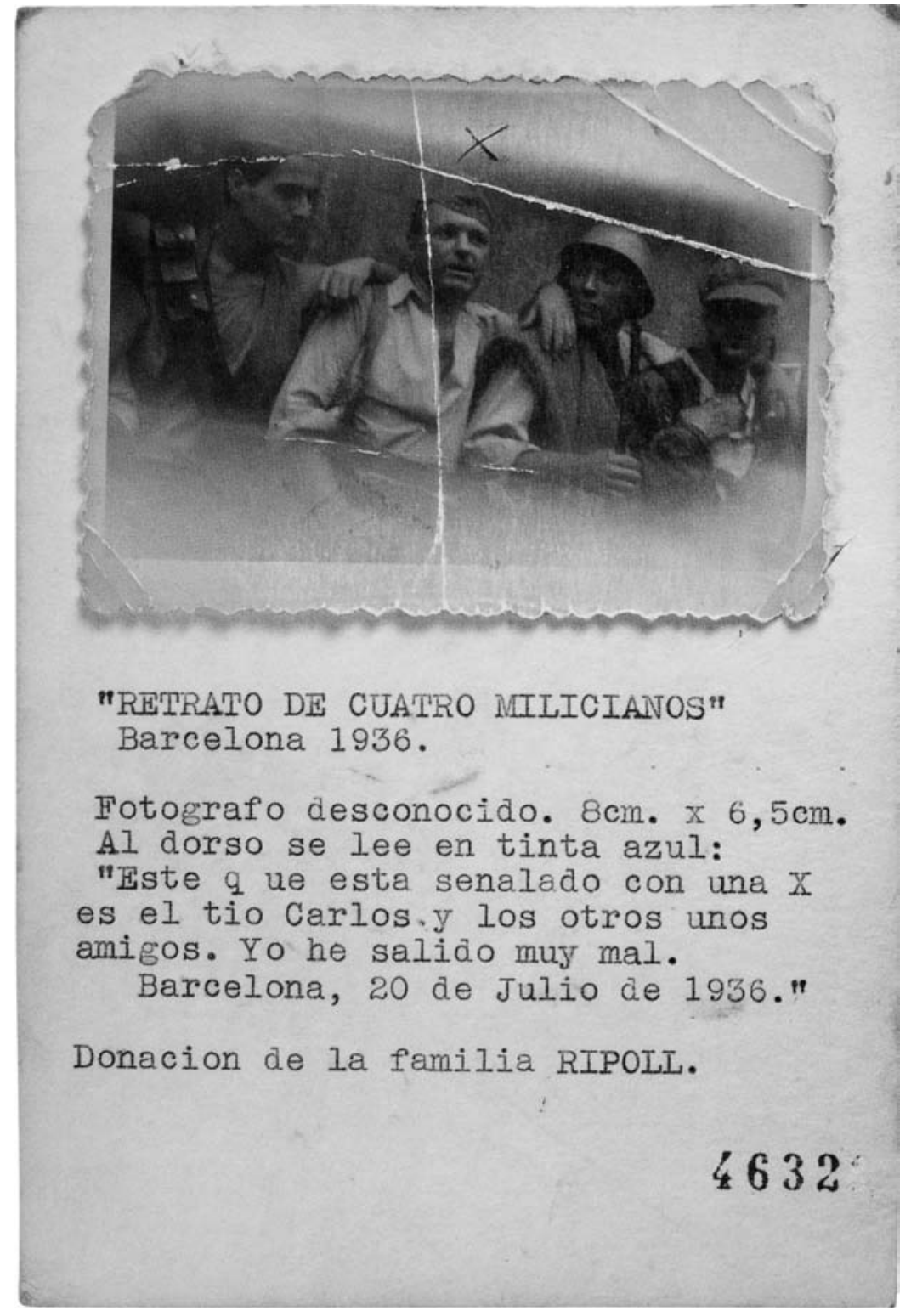

Fig. 1. 


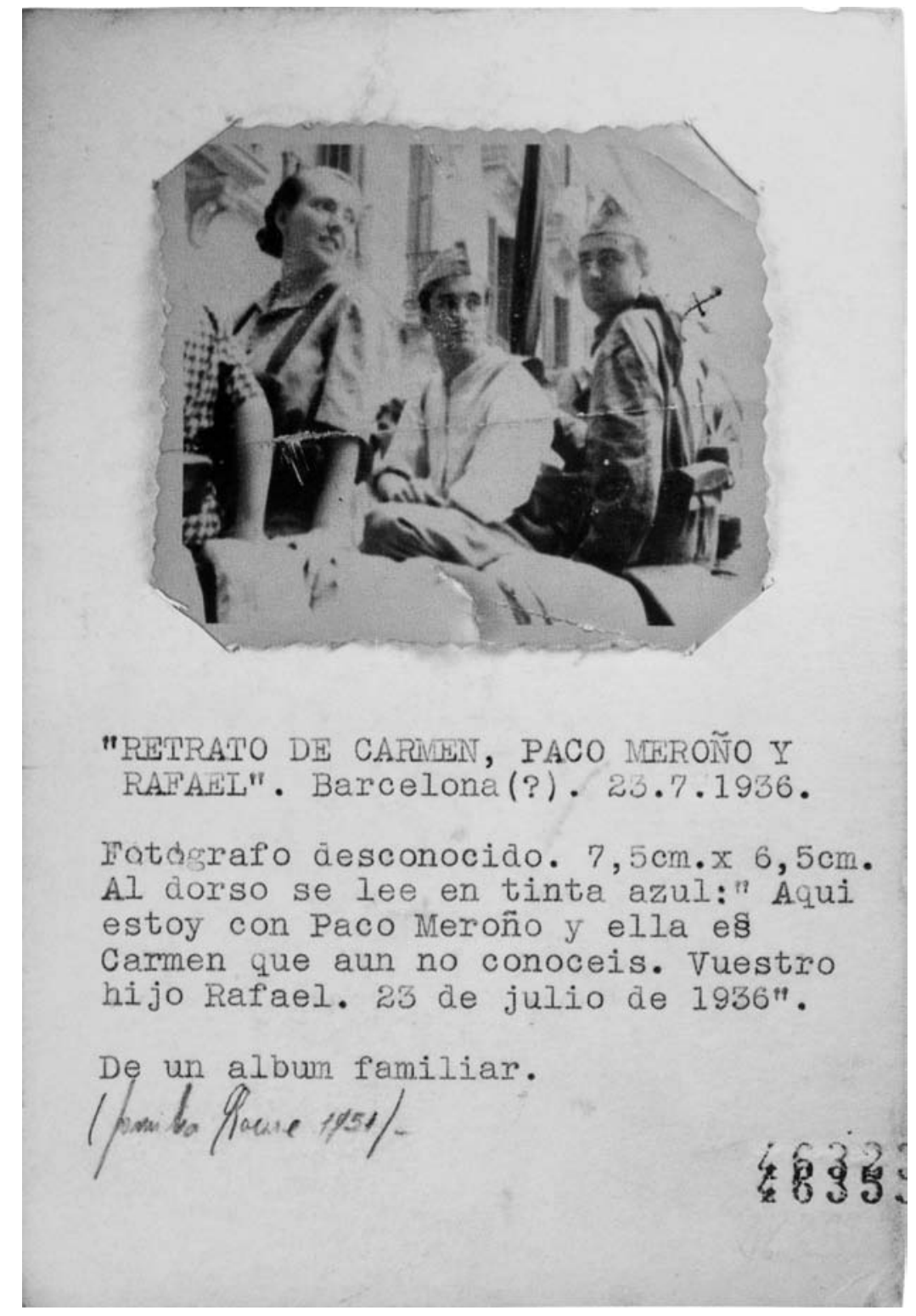

Fig. 2. 
popular army, the "revolutionary" faction of the war. ${ }^{15}$ Thus the title of Llorens's book: the memory of these revolutionaries is materialized in these photographs.

Together in this small book, these photos become a tiny archive of sorts. Facing each image is a "photograph" of the filing card, typed on a vintage typewriter, with misspellings and dropped letters. The information provided is detailed, as to indicate the archival nature of these photographs reproducing any inscription the prints might have (Fig. 1). The transcription captures the imperfection of these notes, as the original photographs have been torn and ripped, adding to a story that is always incomplete, undecipherable, erased (Fig. 3).

The sense of loss in these photographs is strong. They also suggest an additional story, one that conjures up the journey these photographs might have taken before they reached us. The photograph entitled "Retrato de cuatro milicianos" (Fig. 1) invokes this journey: not only because of its worn borders or the damage on the print, but because it is clearly directed at someone, probably a close family member. The snapshot is marked with an $\mathrm{X}$ and the caption that accompanies it clarifies the identity of those in the picture. It reads: "The marked one is Uncle Carlos and the others are friends. I look bad." It is touching to realize how even here there is a worry about how one looks in a picture. It reminds us of Sontag's remark about our relationship with the photograph, the way we are always preoccupied with the way we are captured for posterity (On Photography 85). In the snapshot entitled "Retrato de Carmen, Paco Meroño, y Rafael" (Fig. 2 ), the text inscribed in the photograph is directed to the parents of Rafael, who also has a personal message that tells of the possibility of a future family album. The son, Rafael, introduces Carmen, who he says they have not yet met, implying that they will in the future. This future, the viewer fears, is one that has probably never taken place. The handwritten marks in both of these images also provide a personal touch, as a way to interact with family and to transcend the flatness of the image. The picture of the militiawoman (Fig. 3) reflects the rupture of these familial and private narratives as both image and text have been torn away. The anonymity of the subject is mitigated by the loving text that identifies the woman as dear to the one writing the text, although we, the readers, are only allowed the glimpse of a few words. But the popular romantic convention that sustains these

\footnotetext{
${ }^{15}$ For an account of the experience of the popular army, see Fraser.
} 


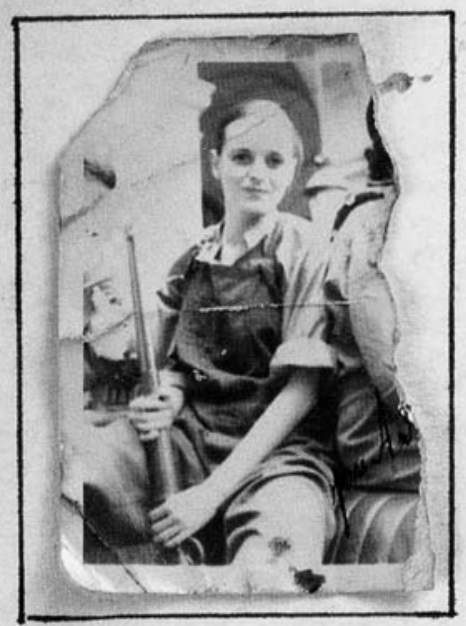

"RETRATO DE UNA MIIICIANA" (roto) *1.936. (?)

Fotografo desconocido. $3,7 \mathrm{~cm}$. $x 5,5 \mathrm{~cm}$.

Se puede leer escrito con lapiz:

"y querida...

este retrato...

para que...

nos separemos ...

tan facil de $\ldots$

como ya sabes"... (a.l dorso).

Cedido de la cற̈leccion TEODORO MORA.

Fig. 3. 
types of narratives quickly helps us to fill in the words, evoking in this broken text and the torn image an unrealized and unfulfilled story.

These photographs, as I revealed at the very beginning of the essay, are fictional. While the photographs themselves are real, their context and stories are entirely imagined. They were taken during the shooting of Vicente Aranda's 1996 film Libertarias, a film about the Spanish Civil War and its popular army, which ironically has been criticized for its hyperreality and its lack of concern about how the past is transmitted to the present (Labanyi, "Teaching" 439). The photographs were part of the 2001/2002 exhibition "La subversión de la realidad" which traveled around Spain and abroad. ${ }^{16}$ Given the title of the show, the viewer in the museum or gallery was aware of the non-veracity of Llorens's work, but the line between reality and fiction is not so clear in the book. Guillem Martínez's ambiguous preface blurs the line between fact and fiction, and even if to the attentive reader its implied message is that the photographs might be unreal, its clear conclusion is that it does not matter that these snapshots do not personally belong to us; we, as viewers, should feel as connected to them as if they were. The book itself also contains a clue, a phrase in the final page that ties the photographs with the filming of Libertarias.

What makes Llorens's photographs interesting is how easily recognizable and comprehensible they are, and alluring to those with a sympathetic view of the losing side of the Spanish Civil War. The question to be asked, then, is not about how or why, but rather what makes his fictionalized images so appealing? ${ }^{17}$ Faced with this question, we must examine the relationship that exists between cultural objects and memory and how history is mediated through them. As Marita Sturken has pointed out, there is often confusion about what we actually know and how much of it comes from private memories or is provided by the news media and popular culture (178-79). Previous exposures to images of war, photographs of those who have participated in them, and our familial relationship to them make Llorens's photographs not only plausible, but real. Given our current media practices, our immediate reaction to the photographic image is that we are faced with evidence of an event that took place. As Sontag has written, images become a reality because they were captured by a camera (On Photography 5).

\footnotetext{
${ }^{16}$ See the catalog Making It Real for information about the exhibit.

${ }^{17}$ Here I take my cue from Laura U. Mark's analysis of fake documentaries who, following Patricia Pisters's work, suggests not to ask if it is moral to fool the audience or about the trueness of the work, but rather what is that they do (201).
} 
In 2008, I met with Martí Llorens to ask him about Memorias revolucionarias. ${ }^{18}$ He invited me to his studio where he showed me the way the photographs were originally displayed in the museum exhibit. He told me of his chance encounter along Las Ramblas in Barcelona with the extras who were being filmed for scenes in the film Libertarias that depicted militiamen and women of the Spanish Republic being transported to the battlefront. Llorens told me how he turned back and ran to his studio to grab his cameras. Walking around the extras, Llorens started taking photographs, mirroring the photojournalists who had accompanied these men and women during the war. ${ }^{19}$ I was curious about what Llorens wanted to capture when he started shooting. His response seemed to reveal that he did not know at the time, but once he was done and developed the photographs, he thought back to the old photographs he saw as a child. He showed me a copy of one of the photographs he used to achieve his final product. He handled the small picture printed in old gelatin type paper to crumple it, he then folded one its ends to show me how it looked like the one his grandfather carried, tucked in a shirt pocket, corner bent, the surface cracked from his constant touching when pulling it out and putting it back. Trying to capture this memory, his project came together as he connected the images he had captured with his own family memories of the past.

The description of Llorens's thought process is clearly connected to Hirsch's concept of postmemory, a powerful and very particular form of memory. It works thanks to its subjective connection, mediated through imaginative investment and creation. In Hirsch's words, "[p] ostmemory characterizes the experience of those who grow up dominated by narratives that preceded their birth" (22). Sarlo has warned that this mediated recollection can become repetitive because it always finds what it searches for (142). Interestingly, in the case of Llorens's Memorias, the fictionality of his images allows us to break this pattern, to question our own assumptions about our knowledge and perception of objects that are familiar to us, such as the photographs of a family album. That is, these fictitious photographs urge us to examine how memory works in terms of its transmission or adoption. But, at the same time, they rely on the affective strength that governs postmemory to tie the viewer's personal history to the experience of

\footnotetext{
${ }^{18}$ The meeting took place in March of 2008. I thank him for his kindness and generosity. The interview was made possible by a Faculty Grant from Bryn Mawr College.

${ }^{19}$ Indeed he mentions war photographers like Capa when narrating the experience of taking these photographs in Making It Real (52).
} 
looking at family albums and photographs of the war, thus cementing the relationship between subject, image, and memory.

Looking at Llorens's photographs, one recalls Sontag's observation about the relationship between death and life in photography, since photographs "state the innocence, the vulnerability of lives heading toward their own destruction, and this link between photography and death haunts all the photographs of people" (On Photography 69). It is no wonder she called the photograph a "memento mori" (15). This relationship between death and photographs is also a story of haunting. Roland Barthes has written about this idea in Camera Lucida (1982), his journey to understand the essence of photographs, rejecting the critical and reductive nature of analysis to concentrate on the connections that happen beyond the identification of the photographic image to its referent. He focuses on the small detail that makes it come alive, acquire meaning, and animate him, "what creates every adventure" (20). For him, the two elements that make up this interaction with photographs are the studium - the social, historical, political information that is transparently communicated by the image, the way he connects with the outside world (26) - and the punctum"that accident which pricks me" (27); it is the latter that speaks to my interpretation of Llorens's photographs. More specifically, what interests me is the capacity of the punctum to move the viewer beyond the visual connection established with the print. ${ }^{20}$

Both Ariella Azoulay and Susie Linfield have remarked on the negative relationship Sontag and Barthes have maintained with photography. Azoulay wrote that they have stopped looking at the images, while Linfield remarked on Sontag's influence in "establishing a tone of suspicion and distrust in photography criticism, and for teaching us that to be smart about photographs means to disparage them" (11; xiv)..$^{21}$ What their criticism brings forth is the need to reconsider the capaciousness of the photograph to move beyond the printed image. But Barthes does signal this shift through his concept of punctum which endows the photograph with a "blind field." He borrows Bazin's cinematic term to expand the "motionless image" of the print image as it were a movie screen, where characters can hide or leave the frame but we know they continue to exist $(59,55-57)$. The enduring effect the punctum produces is what made the photograph memorable: "I

\footnotetext{
${ }^{20}$ Barthes's punctum has been discussed widely and extensively. A good example is Batchen's Photography Zero.

${ }^{21}$ Linfield offers a history of photography criticism that explains this negativity, influenced by postmodernist thought (3-31).
} 
may know better a photograph I remember than a photograph I am looking at, as if direct vision oriented its language wrongly, engaging it in an effort of description which will always miss its point of effect ..." (53). ${ }^{22}$

Azoulay expands on this idea and argues for the need to not only consider what "was there" in a photograph (the contemplative aspect of the punctum) but what continues to be there, engaging (political) action in this process since "a viewing of the photograph that reconstructs the photographic situation and allows a reading of the injury inflicted on others becomes a civil skill, not at exercise in aesthetic appreciation $(94,14)$. In the same vein, Linfield focuses on the idea of the photograph not as a fixed thing but, following Walter Benjamin's thought, something that could be related to the past, present, and future, as a "document of history and possibility" (17). She writes against the relentless suspicion around photographs that have robbed us the ability to "see them" (30). It is time for photography critics "not to drown in pathos or sentimentality but to integrate emotion into the experience of looking" and to use emotion as inspiration for analysis and approach these images about the world with "feeling, immediacy and history" (30-31).

These readings turn the gaze away from a relationship of empathy or mourning and suggest a (politically) active engagement with the photograph..$^{23}$ I would argue, however, that aesthetic appreciation or sympathetically looking at an image need not forego an ethical positioning. Barthers's punctum works as a first step in the process of establishing a relationship with the photograph that could lead to what, for example, Azoulay calls the "civil contract of photography" (16-17). ${ }^{24}$ Ultimately, what is important to understand about the punctum is that which makes an image meaningful not in the moment of viewing, but afterwards. In the case of Llorens's photographs, what makes them likely to be recalled again is their fictionality. While the initial emotive reaction to these photographs may recall the punctum, it is the later awareness of their true nature that truly makes them striking. The

\footnotetext{
${ }^{22}$ Azoulay argues that Barthes sees the photograph only as a "medium," failing to "exhaust the essence of photography" (126).

${ }^{23}$ For example, Azoulay uses the term "to watch" since "[t] he photograph bears the seal of the photographic event, and reconstructing this event requires more than just looking at the photograph and instead start watching it" (14).

${ }^{24}$ She does acknowledge the capacity of the punctum "to transform the photo and the power to extend outward to the social relations in the framework of which it was made" (162).
} 
"blind field" in Llorens's photographs is where their manufactured condition "hides" and what creates the "adventure," adding meaning to the subjects and the event portrayed in the photographer's work.

The fact that these photographs have been deliberately furnished with period authenticity—aged, ripped, bent, stained, cracked—suggests Llorens's intention to convince the viewer that they are a true representation of the past. However, it is only once the fictional nature of these photographs is discovered that their representations start becoming real. What we see "was not there" but suddenly is "here" and continues to be; that is, only after this realization one is able to imagine the actual possibility of the existence of such images. To put it differently, it is precisely the material absence of the referent that makes it real, conjuring it up, filling the photograph not only with context but also with content. Here, it is useful to think of photographs, as Azoulay suggests, as planted in the body, the consciousness, and the memory and, more importantly, of the fact that anyone "can pull at one of its threads and trace in such a way as to reopen the image and renegotiate what it shows, possibly even completely overturning what was seen in it before" (13). As objects of the past, these photographs, however manufactured, open the way to our own memories of the visual legacies of past wars. Couched in the structure of the family album, they not only provide memories and narratives of loss and mourning, but also provide a connection that emphasizes the subjective power of the photograph, "its spooky ability to makes us want to enter the world it depicts and even, sometimes, change it" (Linfield 17). Sontag has described the photograph as "a token of absence" which "attempts to contact or lay claim to another reality" (On Photography 16). This idea, combined with the possibility of change, becomes meaningful in the discussion of the memory and the Spanish Civil War.

One of the last questions I asked Llorens was how important he thought it was for the viewer to know about the fictional nature of his photographs. I referred to my own discovery of his work, not through the museum exhibit where this distinction was clearly exposed, but through the publication of Memorias revolucionarias. At that time, he did not seem to think the question was important, as he drew no distinction between his own memory and his grandfather's, perfectly embodying Hirsch's definition of postmemory. Curiously, years later, when we regained contact through the preparation of this essay, he expressed interest in the ongoing discussion about historical memory and the Spanish Civil War and expressed a critical view of the Spain's 
transition to democracy. ${ }^{25}$ The same way his photographs had become an exercise for me to examine Spain's critical relationship with its past, Llorens himself had gained critical insight through his own fictional photographs of the war. If indeed, as Sontag writes, photographs are tokens of absence, what Memorias revolucionarias reveals are not memories, but their absence. After all, the discourse of victimhood regarding this war has not yet signaled a formal discussion about the government's responsibilities towards past political actions. To attempt to understand the meaning of this silence is to revisit the notion of the archive within the continuing debate around the Spanish Civil War.

\section{Archiving the Spanish Civil War}

Having recognized the special connection between the Spanish Civil War and photography, it is also important to understand the controversy that was created by this relationship. As I mentioned earlier, the most emblematic photograph of the war and the Republican cause, Capa's "The Death of the Loyalist Soldier," was also an image whose authenticity has been questioned. As recently as 2009, the veracity of this photograph was questioned again by José Manuel Susperregui, who relocated the famous image from Cerro Muriano to Espejo (Córdoba), proving that Capa could have not taken a picture during the confrontation to which he linked his photograph. ${ }^{26}$ But even if the photo was indeed staged, it continues to be defended for what it was meant to communicate and still does, the idea of freedom and the willingness to fight for a just cause.$^{27}$ Capa's photograph clearly belongs to the archive of the Spanish Civil War, but it is the controversy that endures around it which captures, maybe too fittingly, the debate that persists around this war, its memories and, finally, its archive.

If the archive, as defined by Foucault, should be thought of as "discursive practices, systems that establish statements as events," what is important to take into account is not their "enunciative possibilities" but the "impossibilities that [the archive] lays down" (128-29). It can no longer be considered a static system of storage but should be seen as an unending project, one that continues to be constructed.

\footnotetext{
${ }^{25}$ Private e-mail correspondence (February 6, 2012).

${ }^{26}$ Catalina Serra's article discusses Susperregui's book in relation to the ICP exhibit of Capa's work.

${ }^{27}$ In the Time article "What Spain Sees . . ." there is an emphasis on what this photograph continues to communicate. Griffith also writes about Capa's photograph as photographic icon (137-41).
} 
As Foucault remarks, the archive is important because it keeps on functioning, as "a practice that causes a multiplicity of statements to emerge as so many regular events, as so many things to be dealt with and manipulated" (129-30). What we should remember about the archive is its imperfection. This limitation may have been exposed publicly during the heated debate that ensued among Spanish historians after the journal Hispania Nova published, from 2006 to 2007, a two-part special issue dedicated to the study of Francoist repression and the discussion (and social activism) regarding the memory of the Spanish Civil War. ${ }^{28}$ Santos Juliá defended himself in a response paper in the journal from what he perceived to be a personal attack not only on his work but his own person (4). His research (and his public presence) had been identified by Francisco Espinosa to be complicit with the discourse of "silence" that permeated Spanish society after the end of the dictatorship. Espinosa refuted Juliá's argument that Spanish society was saturated with memory by pointing to the ubiquity of books and films about the war. He also rejected Juliás explanation that the so called "collective amnesia" was not that Spaniards had forgotten, but that a decision was made to leave behind ("echar al olvido") the past (5-7; Mate 151-55).

While Espinosa engaged in denouncing the systematic silencing that transpired in academic and public institutions when it came to investigating the Civil War, Juliá maintained his innocence and the integrity of his work separating the work of historians from politics, and advocating an impartial and objective study of the past. ${ }^{29}$ Sebastiaan Faber has effectively summarized this discussion, highlighting the crucial points of this debate, one that engages not only the public presence of intellectuals and the coining of the term guerracivilismo [civil-war mongering], the meaning and consequence of the Spanish political transition, especially regarding the treatment of the legacy and memory of the war and the role played by academia and historians in this debate. As he concludes, given the critical and political reaction to the "Ley de Memoria Histórica" after its passing, this dispute is far from over (185-86). ${ }^{30}$

\footnotetext{
${ }^{28}$ Both numbers were coordinated by Sergio Gálvez. Another number has been published in 2012 on the topic of Francoist repression in charge by Julio Aróstegui et al. Available online at hispanianova.rediris.es

${ }^{29}$ The title of his last book illustrates this position: Elogio de Historia en tiempo de Memoria (2011).

${ }^{30}$ The continued publication of works like El estado y la memoria (2009) or Asalto a la memoria (2010) reinforces this impression.
} 
Historian Ludger Mees, drawing from the example of the German Historikerstreit to discuss the case of Spain, has written about the three requisites needed to achieve a lasting and critical recollection of a dictatorship and its crimes in society's collective memory: an academic debate, the non-political involvement of public institutions, and the socialization of debate beyond the circles of academics and intellectuals. He concludes that historians need to mind the latter and should not forget that history is not an exact science ("El pasado"). This concern is clearly directed at the surge of populist pseudo-historians like César Vidal or Pío Moa who have been reinforcing, with great success, a view of the war directly borrowed from the pages of Francoist historiography. But is also revealing when taking into account the increasing popularity of novels about the Spanish Civil war where history is mixed with fiction, and fictionalized personal memories (and experiences) are "recovered" and narrated to fill an imperfect account of the past. For instance, Soldados de Salamina (2001) by Javier Cercas or Mala gente que camina (2006) by Benjamín Prado, are just two examples of the effort to "truthfully" retell the history of the Spanish Civil War and its aftermath. ${ }^{31}$

Given the lack of resolution in the historiographic debate about the Spanish Civil War and the inexistence of proper institutional support to deal with the remembrance of this war, it is not surprising that there has been an appeal to personal recollection as a way to compensate this deficiency. The use of intimate memories to discuss "History" has been criticized, but as Labanyi observes, "[w] hile memory does not give us reliable information about what happened in the past ... it can play a central role in historical understanding by allowing us precisely to see how the past affects the present" ("The Politics" 122). ${ }^{32}$ The public display of personal photographs as an attempt to correct the record of the past exemplifies this situation. I offer two brief examples as illustration of this point: the popular protests surrounding the indictment of Judge Baltazar Garzón in 2010, and public exhibits using family photographs.

Having previously achieved notoriety by attempting to extradite General Pinochet in 1998, Garzón came under fire in 2010 after his

\footnotetext{
${ }^{31}$ In the first case, the author fictionalizes real historical characters like the fascist writer Rafael Sánchez Mazas to offer a plausible account of the war, and in the second case, the writer documents the history of an entirely fictional character during the war and the dictatorship.

${ }^{32}$ Ángel Loureiro has expressed his discomfort around the interest in the past and questions the role emotion could or should play in our understanding of history (226-27).
} 
role in the corruption case involving politicians from the conservative party Partido Popular. His investigation about the disappearance of more than 100,000 people from the time of the Spanish Civil War and the Franco regime for which he ordered the excavation of mass graves also drew heavy criticism. Accused, among other things, of exceeding his authority and violating the amnesty law of 1977, he was defended on the streets by civilians who organized demonstrations under the banner "“Es el momento de las víctimas del franquismo. Saquen sus fotos a la calle!"' ${ }^{33}$ Another instance of the use of personal photographs happened during the opening in Barcelona of the ICP exhibit on Capa, Taro and Chim mentioned earlier. The Museu Nacional d'Art de Catalunya, in conjunction with the newspaper $E l$ Periódico, organized an exhibit entitled "Fém memoria." While the phrase should be translated as "we remember," a literal translation from the Catalan is "we make memory" or "let's make memory." The resulting exhibit included private photographs, snapshots of individuals and their relatives during the Spanish Civil War. ${ }^{34}$

But what does it mean to situate Llorens's work amid this debate about the memory of the Spanish Civil War or to place his photographs in the archive of this war? Let us remember that its most celebrated image is considered by many a staged photograph. This is an archive "tainted" by controversy. Let me offer one final example to reiterate this point. As made clear by the recent publication of the Diccionario biográfico español in 2010, the writing and documentation of the past is still problematic. An ambitious and expensive project sponsored by Spain's Royal Academy of History, the book drew heavy criticism for its entry on Francisco Franco, who was not described as a dictator. ${ }^{35}$ The heated exchange that followed this publication became another moment to reflect on the archive of the civil war and the dictatorship. ${ }^{36}$

\footnotetext{
${ }^{33}$ The banner was used as the title of an article that was published in El País in 2010. The demonstrations were scheduled to be repeated in front of Spanish embassies in Paris, Brussels, London, Buenos Aires, etc. Garzón was, at the end, indicted for illegal wiretapping, for investigating Francoist crimes despite the amnesty law of 1977, and for irregularities regarding his compensation during his travels outside of Spain. On February 9, 2012, the Supreme Court of Spain convicted him of illegal wiretapping and disqualified him from judicial activities for eleven years. There was a public (and some political) outcry following this conviction. A few days later, he was acquitted from overstepping his authority in investigating crimes under the dictatorship and the fraud charge was dismissed on a technicality.

${ }^{34}$ The resulting gallery of images can be accessed at http://memoria.elperiodico. cat/GaleriaFotos.aspx.

${ }^{35}$ The entry was prepared by Luis Suárez, a medievalist. For an overview of the controversy, see "Franco ese (no tan mal) hombre."

${ }^{36}$ The Royal Academy of History has decided in February 2012 not to emend Franco's biography ("Insistimos").
} 
In Archive Fever (1995), Derrida writes about the archive in relation to the future, not the past. While the archive is the result of a look back towards the past, its meaning rests on its gesture towards the future. For instance, Derrida discusses the relationship between the archive and memory, and questions this connection as the archive can never be closed and opens out to the future through its own repetition (Archive 68 ). As he points out, the process in which "archivization" works is that it also "produces as much as it records the event," determining thus the very institution and future of the archive (17-18). The writing of Franco's biography should tell us something about the gesture towards the future in the archive of the Spanish Civil War. ${ }^{37}$

Derrida acknowledges the imperfect and constructed nature of the archive but, more importantly, points to its future-oriented structure as "what confronts us with a responsibility, an ethical and political responsibility" ("Archive" 46). This responsibility demands that we pay attention to the way we acquire our knowledge of the past, not only in order to understand our present, but also to make sure this experience informs our future. The open-ended and constructed nature of the archive serves to continue the work of memory. In fact, I would suggest that Llorens's photographs should be interpreted as examples of why the archive of the Spanish Civil War is still (and must remain) an ongoing project. To illustrate this point, it is useful to consider Hal Foster's explanation of archival art, one that deals with the past and its documentation, as a construction site rather than an excavation site (22). "Archival artists" are, as defined by Foster, "seek[ing] to make historical information often lost or displaced, physically present" (4). The sources of their work are often familiar, "drawn from the archives of mass culture, to ensure a legibility that can then be disturbed or detourné; but they can also be obscure, retrieved in a gesture of alternative knowledge or counter-memory" (4). Exploring further the notion of "archival art," the critic describes "all archival materials as found yet constructed, factual yet fictive, public yet private" (5-6). In the same way Llorens tapped into existing memories and cultural references to make his images and texts familiar, this process also helps him make his work factual despite its fictitiousness. Echoing Derrida's reflections on the archive, Foster suggests that "[p] erhaps all archives develop in this way, through mutations of connection and disconnection, a

\footnotetext{
${ }^{37}$ For instance, it should be pointed out that part of the Law of Historical Memory is devoted to the creation of a Centro Documental de Memoria Histórica. What remains to be seen is which documents (or memories) will be included in its collection.
} 
process that this art also serves to disclose" (6). The use of the archive in Llorens's project should help the viewer realize the operative logic of his work, one that relies on the archival impulse to contest the pervasiveness and authority of the archive. Engaging with the past to try to document its experience through manipulation reveals the imperfection of the archive, and the limitations of our memory and our effort to document it.

In Llorens's work, the effort to provide period authenticity to his photographs becomes a reflection of the produced nature of this archive. If, on the one hand, his work could warn us about the abundance of images related to the Spanish Civil War surfacing to become part of our collective memory without mediation or critical insight, then on the other hand, it also reveals the way archives can be constructed and their legitimacy questioned. His work is a reminder of how memories are made, accessed, recreated and manipulated. This realization is important because "it suggests a shift away from a melancholic culture that views the historical as little more than the traumatic" (Foster 22). Llorens's photographs are not meant to be an end in themselves, artifacts or "memory objects" that reveal a fetishistic relationship with the past. They should be seen as recreations of the past that can help us evaluate our connection to the past. His work does not produce historical facts about the war or about the soldiers who lost it, but makes them "present" through the discourse and rituals of a family album. From private to public, these snapshots question the symbolic order at large, challenging dominant fictions that try to normalize our relationship with history, converting the past into a construction site, where memories can be produced and manufactured to ultimately ensure its legibility.

Bryn Mawr College

\section{WORKS CITED}

Aguilar, Paloma. Memory and Amnesia: The Role of the Spanish Civil War in the Transition to Democracy. Trans. Mark Oakley. New York: Berghahn Books, 2002. Print.

Aranda, Vicente, dir. Libertarias. 1996. Film.

Aróstegui, Julio and François Godicheau, eds. Guerra Civil. Mito y memoria. Madrid: Marcial Pons, 2006. Print.

Azoulay, Ariella. The Civil Contract of Photography. New York: Zone Books, 2008. Print.

Barthes, Roland. Camera Lucida. Reflections on Photography. Trans. Richard Howard. London: Jonathan Cape, 1982. Print.

Batchen, Geoffrey. Photography Degree Zero: Reflections on Roland Barthes's Camera Lucida. Cambridge, MA: MIT P, 2009. Print. 
Boletín Oficial del Estado. Ley por la que se reconocen y amplían derechos y se establecen medidas en favor de quienes padecieron persecución o violencia durante la guerra civil y la dictadura. Vol. Ley 52/2007. 2007. Web. 10 Dec. 2011.

Casanova, Julián et al. Morir, matar, sobrevivir: la violencia en la dictadura de Franco. Barcelona: Editorial Crítica, 2004. Print.

Cercas, Javier. Soldados de Salamina. Barcelona: Tusquets Editores, 2001. Print.

Constenla, Tereixa. "Franco, ese (no tan mal) hombre." El País 30 May 2011. Web. 2 Dec. 2011.

Derrida, Jacques. Archive Fever: A Freudian Impression. Chicago: U of Chicago P, 1996. Print. . "Archive Fever in South Africa." Refiguring the Archive. Eds. Carolyn Hamiltonet al. Dordrecht, The Netherlands: Kluwer Academic Publishers, 2001. 38-80. Print.

Espinosa, Francisco. "De saturaciones y olvidos. Reflexiones en torno a un pasado que no puede pasar." Hispania Nova 7 (2007): n. pag. Web. 3 June 2012.

— La columna de la muerte: el avance del ejército franquista de Sevilla a Badajoz. Barcelona: Editorial Crítica, 2003. Print.

Faber, Sebastiaan. "The Debate About Spain's Past and the Crisis of Academic Legitimacy: The Case of Santos Juliá." The Colorado Review of Hispanic Studies 5.Fall (2007): 165-90. Web. 3 June 2012.

Fraser, Ronald. "The Popular Experience of War and Revolution 1936-39." Revolution and War in Spain, 1931-1939. Ed. Paul Preston. London: Methuen, 1984. 225-42. Print.

"Fem memòria." Virtual Gallery from El Periódico. 14 Sept. 2011. Web. 10 Dec. 2011.

Foster, Hal. "An Archival Impulse." October 110 (2004): 3-22. Print.

Foucault, Michel. Archaeology of Knowledge. London and New York: Routledge, 2002. Print.

Griffin, Michael. "The Great War Photographs: Constructing Myths of History and Photojournalism." Picturing the Past: Media, History, and Photography. Eds. Bonnie Brennen and Hanno Hardt. Urbana: U of Illinois P, 1999. 122-57. Print.

Guixé, Jordi. "Espacios, memoria y territorio, un memorial en red en Cataluña." Vinyes 569-604.

Hirsch, Marianne. Family Frames. Photography Narrative and Postmemory. Cambridge, MA: Harvard UP, 1997. Print.

Izquierdo Martín, Jesús, and Pablo Sánchez León. La guerra que nos han contado. 1936 y nosotros. Madrid: Alianza Editorial, 2006. Print.

Junquera, Natalia. “'Es el momento de las víctimas del franquismo. Saquen sus fotos a la calle!'” El País 22 Apr. 2010. Web. 8 Dec. 2011.

Juliá, Santos. Elogio de Historia en tiempo de Memoria. Madrid: Marcial Pons, 2011. Print.

"De nuestras memorias y de nuestras miserias." Hispania Nova 7 (2007): n. pag. Web. 3 June 2012.

Kennedy, Randy. "The Capa Cache.” The New York Times 27 Jan. 2008. Web. 25 Oct. 2011.

Kim, Yeon-Soo. The Family Album. Histories, Subjectivities, and Immigration in Contemporary Spanish Culture. Lewisburg: Bucknell UP, 2005. Print.

Labanyi, Jo. "The Politics of Memory in Contemporary Spain." Journal of Spanish Cultural Studies 9 (2008): 119-125. Print.

_. "Entrevista con Emilio Silva." Journal of Spanish Cultural Studies 9.2 (July 2008): 143-155. Print.

"Teaching History through Memory Work: Issues of Memorialization in Representations of the Spanish Civil War." Teaching Representations of the Spanish Civil 
War. Ed. Nöel Valis. New York: The Modern Language Association of America, 2007. 436-50. Print.

Linfield, Susie. The Cruel Radiance. Photography and Political Violence. Chicago: U of Chicago P, 2010. Print.

Llorens, Martí. Memorias revolucionarias. Murcia: Mestizo, 1999. Print.

Loureiro, Ángel G. "Pathetic Arguments.” Journal of Spanish Cultural Studies 9.2 (2008): 225-237. Print.

Marks, Laura U. "Signs of the Time. Deleuze, Peirce, and the Documentary Image." The Brain is the Screen. Deleuze and the Philosophy of Cinema. Ed. Gregory Flaxman. Minneapolis: U of Minnesota P, 2000. 193-214. Print.

"Martí Llorens." Síntesis: 15 años de Becas Endesa: Edificio Endesa, Madrid, 25 de octubre-8 de enero, 2005. Comp. Ana Isabel Herce. Teruel, Spain: Museo de Teruel, Diputación de Teruel; Madrid: Fundación Endesa, c2005. Print.

Mate, Reyes. La herencia del olvido. Madrid: Errata naturae, 2008. Print.

Mees, Ludger. "El pasado que no quiere pasar." El País. 15 Sept. 2006. Web. 17 June 2012.

Pingree, Geoff. "What Spain Sees in Robert Capa's Civil War Photo." Time July 2009. Web. 10 Dec. 2011.

Prado, Benjamín. Mala gente que camina. Madrid: Alfaguara, 2006. Print.

Preston, Paul. The Spanish Holocaust: Inquisition and Extermination in Twentieth-Century Spain. London: Harper, 2012. Print.

Riaño, Peio H. "Insistimos: Franco no fue totalitario.” El País 10 Feb. 2012. Web. 15 June 2012.

Sánchez León, Pablo. "La objetividad como ortodoxia: los historiadores y el conocimiento de la guerra civil española.” Aróstegui and Godicheau 95-135. Print.

Sante, Luc, and Vik Muniz. Making It Real: A Traveling Exhibition. New York: Independent Curators Inc, 1997. Print.

Sarlo, Beatriz. Tiempo Pasado. Cultura de la memoria y giro subjetivo. Una discusión. Buenos Aires: Siglo XXI, 2007. Print.

Serra, Catalina. "Capa y Gerda Taro, polémica sin fin.” El País 17 July 2009. Web. 11 Nov. 2011.

Sontag, Susan. Regarding the Pain of Others. New York: Picador, 2003. Print.

- On Photography. New York: Picador: 1977. Print.

Sturken, Marita. "The Image as Memorial: Personal Photographs in Cultural Memory." The Familial Gaze. Ed. Marianne Hirsch. Hanover, NH: UP of New England, 1999: 178-95. Print.

Updike, John. "Visual Trophies. The Art of Snapshots." The New Yorker 24 Dec. 2007. Web. 29 Nov. 2011.

Vinyes, Ricard. Asalto a la memoria. Impunidades y reconciliaciones, símbolos y éticas. Barcelona: Los libros del lince, 2011. Print.

- ed. El estado y la memoria. Gobiernos y ciudadanos frente a los traumas de la historia. Barcelona: RBA Libros, 2009. Print. 